\title{
After FOCAC: Have China-Africa relations finally turned a corner, or was FOCAC V simply more of the same?
}

\author{
By Matthew McDonald, \\ Research Analyst, Centre for Chinese Studies
}

\begin{abstract}
Recently, African Heads of State and China met in Beijing for the fifth FOCAC ministerial meeting, the latest in a twelve year process that has seen increasing exchanges of capital, goods and services, scholarship and people between the continent and China. The increasing value of this relationship is probably best illustrated by the consecutively larger financial overtures China has made to Africa at each respective event; in 2006 China promised US $\$ 5$ billion in loans and assistance, in 2009 , they doubled it to US $\$ 10$ billion, and in mid-July 2012, President Hu again doubled China's African stake with a promise of US $\$ 20$ billion in loans and credit over the next three years. Attendance was unlike the summit in 2006, though, less than a quarter of leaders of the fifty registered FOCAC members actually pitched up, though most states did send at least some sort of ministerial or diplomatic representation. This turnout was more likely due to China's last minute shifting of the conference from end October to end July, than some sort of antagonism from the African side.
\end{abstract}

From the media response, you might imagine this was the single greatest thing that occurred during those two days - and indeed, it's a hefty (promise of) investment in the relationship going forward, but it's also nothing new. Africa is a long time recipient of Chinese largesse, as the continent of foreign and commercial policy interest to China. However, looking past the diplomatic pomp and pageantry, and setting aside the big figure promises pasted across the headlines for a moment, the FOCAC $\vee$ also signified something both a little less expected, and that many in the China-Africa game have been waiting for a while to see.

\section{Finally, an African country at FOCAC publicly leveraged the significant African stake in the relationship and gave praise - and some criticism of the existing relations.}

\section{The hand that feeds it}

Finally, an African country at FOCAC publicly leveraged the significant African stake in the relationship and gave praise - and some criticism of the existing relations. China seemed to sense this: witness some highest-level self-criticism and their even larger basket of commitments to Africans, casting the extraordinary financial commitment and assorted other promises to keep their African deals sweeter than sweet in something of a new light. What's going on?

Praising the collegiality of the relations China maintained with African states via FOCAC is no news from an African president - and mostly fulfils the function of adhering to Chinese protocol while offering an indirect stab at condition-laden loans and assistance from traditional donors in the northern hemisphere. Yet, besides this nicety, President Zuma of South Africa told the assembled Chinese and African dignitaries and delegates:

"Africa's commitment to China's development has been demonstrated by supply of raw materials, other products and technology transfer. This trade pattern is unsustainable in the long term. Africa's past economic experience with Europe dictates a need to be cautious when entering into partnerships with other economies."

That's quite something to say to the nation whose trade exchange with your continent tripled in value in from 2006 to 2011 to US $\$ 166.3$ billion, and no less a barb for the one 
country that is your own nation's largest trading partner - speaking in Sino-South African terms. But it's also something that's needed to be said from the African side for years. Habitually, it's civil society, or academia, that crow loudest in respective states, and across various sectors of mutual interest, for more accountability, transparency, and attention to often neglected elements of international investment, such as environmental protection. Analysts (including this Centre) have called on African governments in the past to present an assertive response to Chinese entreaties for trade, assistance and investment. Zuma's comments indicate that African governments are ready to turn this trend around.

President Hu even spoke to the inequalities and imbalances in the relationship thus far. It remains to the observers to understand if he was speaking perhaps not only to the trade imbalance that favours Chinese imports, but also to the many calls for coherence in Chinese engagement. Hu called to address these imbalances by regulating access of Chinese companies, or better systems to help balance the effects of Chinese labour shipped in to work on big figure infrastructure and extraction projects. Not only were promises made to train 30,000 African workers alongside big figure projects, increase the number of scholarships to African students to 18,000 and swell the Chinese medical cohort in Africa to 1,500 , but China finally made the much needed commitments to Africa's environmental security that civil societies both on the continent and outside it have been demanding for years. Specific topics in this realm are water security and forest protection.

\section{IJ From the outside, it may well appear that China is bending over backwards for its African friends.}

From the outside, it may well appear that China is bending over backwards for its African friends (though the actual disbursement of the promised credit, the particular mix of loan and assistance that is applied, and the precise figures for African countries that will ultimately benefit from the facility are not on the table yet), and those friends (well, at least some of them) finally seem to be approaching the relationship from the perspective of what do we need from you rather than the all too familiar what can we get from you. This is a welcome shift.

Pulling back from the China-Africa relationship alone - it may finally be a signal that African economies are realizing that China is not the only game in town; there are other developed and developing nations interested in Africa's markets and commodities whose interest in African markets and resources can be played against one another, or even invited in concert. Contrarily, that China has realized it's going to have to keep sweetening Africa to the opportunities of relations with Beijing, because other developing nations - no less its BRICS colleagues, are already hard at work attempting to woo African markets and investment opportunities. China will need to optimise its offering if it want's the optimal share of African business and resources.

What factors could possibly support the hope that Africa is finally finding its footing in the relationship that has defined Africa's $21^{\text {st }}$ Century to date? A couple come to mind:

\section{China is not the only dish on Africa's menu}

Regarding the trade levels between Africa and China - the immediate perception is the spiralling value of trade between African countries and China in the last decade or so the value of which has tripled, as stated above, in the half decade between 2006 and 2011. What the Financial Times was quick to point out though was the sometimes ignored percentage of world trade that Sino-African trade occupies; despite all the excitement and attention, trade between all of Africa and China is still only the size of 
Chinese trade with Australia. Observe the chart below generated by the Financial Times (Online; 2012) a few days after the end of the FOCAC in Beijing.

The red bars indicate the volume of trade between Africa and China in the years since 2000 , and despite the expectable dip during the 2008 financial crisis, the picture, like the bar graph, is rosy. Observe the single blue line - which charts the percentage share of world trade held by Sino-African trade since 2000. Since late 2010, it has basically flat lined, indicating not a slump in volume, of course, but that both China, and the African countries counted, are enjoying an increasing diversity of export partners. Their trade is growing, but not necessarily only with each other. Indeed, besides the traditional partners (the developed world), Africa is enjoying heretofore unprecedented attention from the emerging economies like those in the BRICS, as well as other Asian economies like Turkey and Korea. China's largesse this time very much signals a deepening of its relations with Africa in a time when increasingly it faces competition on the continent from other emerging powers - and some more disenchantment with China on the continent, ten years after engagement increased substantially.

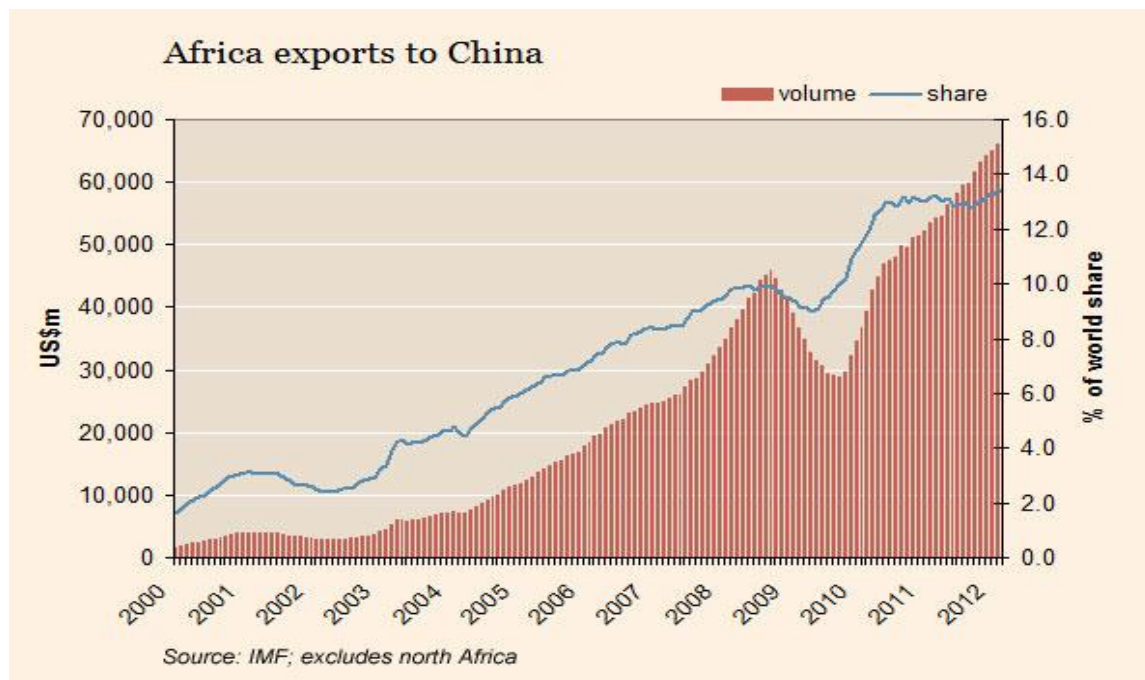

\section{II \\ As early as two years ago, Chinese growth analysts were predicting a significant slowdown in the Chinese economic miracle.}

\section{A friend in need}

As early as two years ago, Chinese growth analysts were predicting a significant slowdown in the Chinese economic miracle - a three decades long double digit growth streak that propelled what was once one of the world's most isolated and underdeveloped nations to the second largest economy behind the United States. As of mid2012, China's growth has slumped (an ironic label given few other states can even boast such growth figures) to around $7.5 \%$; these rates, however, are not sustainable. With an ageing population, and massive income disparity, the decision was announced two years ago via the CCP's most recent Five Year Plan to settle on slower growth and focus on stabilizing Chinese society by boosting domestic spending. Best laid plans aside, no-one could have expected quite how much the Chinese economy has slowed down - by no means to economic crisis level, but certainly the slowing of certain key sectors was unexpected. The crisis might be rather grasped as political, though, as the social inequalities in China are daunting - and even harder to address when growth slows. On a recent trip to China, one of our CCS Research fellows chatted to Chinese business owners in a busy Shanghai market, who complained at the rate of economic 
slowdown. China's increased focus on consumption driven growth over export driven growth, coupled with the dire state of the international economy has seen international orders for Chinese goods and services take a tumble. Facing slowing growth, China needs African resources and markets more than ever - and now must compete with even more emerging economies looking for entry into the continents four dozen, often growing economies. Africa is one of the few markets where trade with China has kept expanding, and likewise for African exports to China - pegged at US\$93.2 billion last year (mostly commodities).

Even before the FOCAC kicked off last week, the Chinese Premier, Wen Jiabao indicated that the upcoming ministerial meeting would seek to address the "imbalance" (CRI; 23 July 2012) in China's trade with Africa - they're likely to start importing more finished goods, as well as addressing African-side skills shortages in several sectors of mutual cooperation. As such, the trade imbalance and undue advantage to Chinese labour have been on the table since FOCAC began twelve years ago, but now, given the leverage African countries seem to be willing to take, and the need for China to maintain its string financial ties with the continent, in the face of mounting grassroots opposition from African societies (not unlike China internally, by the way), the time may have come for China to make good on these commitments.

\section{0 \\ What is immediately remarkable about the Declaration this time round is the explicitly more international tinge to the proceedings.

\section{So what's in it for Africa this time round?}

Typically, FOCAC meetings are followed by the release of two documents- the first is a Declaration premised on the original declaration made in Beijing in 2000 at the end of the first FOCAC. It recalls the vision for FOCAC as perceived by the Chinese and African delegations present, and briefly summarises the areas of interest where relations will be moving forward. The second, a Plan of Action, is much more comprehensive as it physically describes the path the stakeholders want the relationship to take until the following FOCAC three years hence.

What is immediately remarkable about the Declaration this time round is the explicitly more international tinge to the proceedings. FOCAC has, to date, resisted the pull to become a fully-fledged multilateral institution, but with representation from the African Union (AU) and African Commission (AC) present, not to mention the UN Secretary General, and with China's deepening experience in both the more formal set of institutional organizations, and the more informal (BRICS), plus the increased scope of China-Africa activity that the document premises - from the international financial architecture, to agricultural reform, via the UNFCCC (United Nations Framework Convention on Climate Change) and Rio+20 - there are distinct indications here of a future where FOCAC can become more than a cluster of bilateral exchanges across various areas of interests.

The main gist of the Declaration (FOCAC; 2012) is the much-anticipated "new strategic partnership" between China and African states - a significant embellishment of the already existing modes of cooperation and areas of collaboration focused around six points;

- African political discourse and governance, "on such issues as sovereignty, independence, security, unity, territorial integrity and national development, so as 
to increase the political trust and strategic consensus between China and Africa." (note the absent points here - in comparison to aspects the West emphasises; little is said of interdependence or global responsibilities),

- African peace and security and the international dimensions of that,

- Interaction with and between African regional organisations (including the AU) with respect to support and development mechanisms (i.e. the AU's programme on socio-economic development, Nepad),

- Enhance cooperation and respect "comparative advantage" in almost a dozen areas, including trade, security, development, poverty reduction, infrastructureand capacity building, and development of both human- and non-human resources- all in all, a pretty broad stroke,

- Enhance cooperation in non-traditional zones of cooperation including culture, education, sports, tourism and other fields, and forge closer ties between the young people, women, non-governmental organizations, media organizations and academic institutions; environmental aspects are also mentioned, but, again, more as an afterthought,

- Enhance the cooperation in international affairs and institutions, with due regard "to each other's legitimate concerns and aspirations."

11 Emphasis [is] placed on African agency in the relationships - the concept of a partnership of equals.

The main innovation in all this, most of which we have seen in previous FOCAC literature, is the additional emphasis placed on African agency in the relationships - the concept of a partnership of equals. Of course, in reality, there is much work to be done to make the relations between any of the African states in FOCAC equitable with China. But there is scope here for improvement, if African countries can harness the spark of South African President Zuma's words at the summit in Beijing, that, as they are now- Africa's economic relationship with China is unsustainable, then perhaps the systemic change needed in Sino-African relations can begin to take shape. That goes for relations in many other zones of mutual interest too.

The Action Plan puts more meat on the bones of this new Strategic Partnership - focusing on individual sectors of mutual concern. Again, there is enhancement of commitments in practically every sector- now arranged into sections reflecting the new "strategic partnership" the architects of FOCAC hope to introduce into the language; Political Affairs and Regional Peace and Security, Cooperation in International Affairs, Economic Cooperation, Cooperation in the Field of Development, and Cultural and People-ToPeople Exchanges and Cooperation. The scope of interaction is much more explicitly fleshed out- reflecting again the Declaration's impetus to include all levels and fields of African society - from diplomatic-, party- and government dialogues, through finance-, banking-, transportation-, energy- and tourism sectors, via academia, think tanks and youth and women exchanges, just to select a handful of the elements mentioned.

So what's in it for Africa? The fact is that yes, these documents merely outline the desired outcomes the assorted FOCAC delegations are eyeing for the next three years, and, as such, actual execution of much of these outcomes will be the subject of a lot more leg work between Chinese agencies and individual countries and agencies in Africa- these are not contractual obligations. There is a shift in the language, and the scope of the sectors and issues addressed- and these shifts should be heartening to African societies and interest-led factions within them, particularly with reference to the environmental protection and climate change issues. Note the should be, since there is some way to go 
still before these issues become priorities for the majority of African states, their private and public sectors.

Of more immediate interest to most will be the financial commitments- particularly the US $\$ 20$ billion credit line- which of course will be extended to countries where lucrative investment and infrastructure deals are to be found. What was more interesting in those sections were the commitments to African financial institutions- the CADfund is to receive a (gradual) US $\$ 5$ billion boost, and cooperation with the African Development Bank is to be boosted, as well as with regional financial institutions.

There is a visible shift towards stimulating and coalescing Africa's often marginal agency in international affairs- couched in familiar terms of "developing partners, and the global south"; and towards supporting African institutions, be they continental, regional or in-country - particularly in the area of peace and security. The upheavals in (North) African governments last year and the year before cannot have been far from anyone's minds. There is also significant presence of international institutions and formations in the Action Plan - a clear prioritising of Africa's international agenda whether via the development of the BRICS, the ongoing processes of the Rio+20, or the more formal (and cumbersome) machinations of the UN, its assorted suborganisations, or associated financial institutions.

17 There is a visible shift towards stimulating and coalescing Africa's often marginal agency in international affairs- couched in familiar terms of "developing partners, and the global south";

The onus has never been more on Africans to capitalise on the opportunities littering this arrangement. The gauntlet has been thrown down by South Africa- the current economic relationship cannot move forward in its current state, and now even more nations and economic blocs are shopping the continent for resources, for access, and for investment, no less from China which appears to be bending over backward to accommodate issues no-one ever dreamed would feature on the agenda of a forum like this even five years ago. The task now is for African states and leaders to find the optimum geometry to hold big investors like China to the words of this Plan - be it in concert via continental or regional organisations, be it arranged in issue-focused blocs or groups, or be it via their bilateral channels. FOCAC $\vee$ highlighted Chinese interests in Africa and was an insistent invitation to step up, one that African countries can no longer ignore.

\section{References}

China Radio International. "China Lays out Plans to Increase Sino-Africa Ties" - 23 July 2012. Online: http://bit.ly/PbvvBV . Accessed: 23 July 2012.

Financial Times Online. "Chart of the week: China steps up the Africa charm offensive" - 23 July 2012. Online: http://on.ft.com/OiTPOn. Accessed: 23 July 2012.

Forum on China-Africa Cooperation. 2012. Beijing Declaration of the Fifth Ministerial Conference of the Forum On China-Africa Cooperation. Online: http://bit.ly/MZnyLO. Accessed: 23 July 2012.

Forum on China-Africa Cooperation. 2012. The Fifth Ministerial Conference of the Forum On China-Africa Cooperation Beijing Action Plan (2013-2015). Online: http://bit.ly/MiWXuH Accessed: 24 July 2012.

Matthew McDonald is a research analyst at the Centre for Chinese Studies,

Stellenbosch University. 厤 